\title{
PERMAINAN GERAK DASAR LOKOMOTOR UNTUK ANAK TUNAGRAHITA SEDANG
}

\author{
M. Haris Satria ${ }^{1}$, Made Agus Wijaya ${ }^{2}$ \\ ${ }^{1}$ Pendidikan Olahraga, Universitas Bina Darma \\ Palembang, Indonesia \\ ${ }^{2}$ Program Studi Penjaskesrek, Universitas Pendidikan Ganesha, \\ Singaraja, Indonesia \\ e-mail : $\underline{\text { haris@binadarma.ac.id, wijaya.madeagus@undiksha.ac.id }}$
}

\begin{abstract}
Abstrak
Tujuan dari penelitian ini yaitu untuk mengembangkan permainan gerak dasar lokomotor untuk anak tunagrahita sedang.penelitian ini merupakan penelitian dan pengembangan. Sampel dalam penelitian ini berjumlah 36 orang dari tiga SD SLB C di Kota Palembang. Hasil penelitian menunjukkan bahwa permainan gerak dasar lokomotor untuk anak tunagrahita sedang dapat diaplikasikan akan tetapi dengan intruksi penuh serta pendampingan lebih. Hasil uji efektifitas juga menunjukkan bahwa model ini efektif yang dilihat dari hasil $t_{-}$(hitung) $=17.50>t_{-}$(tabel) $=2,028$ sehingga terima Ha dengan Signifikan. Saran dari penelitian ini yaitu para guru/pelatih dapat menggunakan model ini baik dalam pembelajaran maupun latihan akan tetapi dengan pendampingan.
\end{abstract}

Kata-kata kunci: permainan, lokomotor, tunagrahita

\begin{abstract}
The purpose of this study is to develop a basic locomotor motion game for mentally retarded children. This research is a research \& development. In this study, there were 36 people from three SLB C elementary schools in Palembang. The results showed that the locomotor basic motion games for mentally retarded children could be applied but with full instructions and more assistance. The effectiveness test results also show that this model is effective as seen from the results of the $t$ test where $t_{-}$(count) $=17.50>t_{-}$ (table $)=2,028$ so accept Ha significantly. The suggestion from this research is that teachers/trainers can use this model both in learning and in practice but with assistance.
\end{abstract}

Keyword: play, locomotor, mental retardation 


\section{PENDAHULUAN}

Anak tunagrahita adalah anak yang mengalami masalah atau gangguan intelektual dimana kecerdasan intelektual mereka berada di bawah rata-rata berdasarkan taraf intelegensi dan juga mengalami gangguan dalam berinteraksi sosial. Hal ini sejalan dengan pendapat Somantri (2007) yang mengatakan bahwa tunagrahita adalah istilah yang digunakan untuk menyebut anak yang mempunyai kemampuan intelektual di bawah rata-rata dalam arti lain yaitu kondisi anak yang kecerdasannya jauh di bawah rata-rata dan ditandai oleh keterbatasan intelegensi dan ketidakcakapan dalam interaksi sosial. Selanjutnya menurut Dadan (2013) seseorang dikatakan mengalami ketunagrahitaan adalah individu yang memiliki intelegensi yang signifikan berada di bawah rata-rata dan disertai dengan ketidakmampuan dalam adaptasi perilaku yang muncul dalam masa perkembangan. Sedangkan menurut Kemis dan Ati (2013) bahwa tunagrahita adalah kelainan yang meliputi fungsi intelektual umum di bawah rata-rata (sub-average) yaitu IQ 84 ke bawah sesuai tes, kelainannya muncul sebelum usia 16 tahun dan kelainan yang menunjukkan hambatan dalam perilaku adaptif.

Anak tunagrahita pada umumnya diklasifikasikan berdasarkan tingkat intelegensinya. Menurut Somantri (2007) mengacu pada tes Stanford Binet bahwa klasifikasi anak tunagrahita terdiri dari : (1) tunagrahita ringan (IQ antara 68-52), (2) tunagrahita sedang (IQ antara 51-36), tunagrahita berat (IQ antara 32-20), (4) tuangarhita sangat berat (IQ < 19). Melihat dari klasifikasi tesebut bahwa diperlukan lembaga pendidikan untuk memfasilitasi anak tunagrahita.

Lembaga pendidikan tidak hanya ditujukan/diperuntukkan bagi anak yang dalam arti normal (fisiknya lengkap, intelektualnya baik dan perilaku sosialnya juga baik) akan tetapi juga diperuntukkan bagi anak yang mengalami gangguan intelektual dalam hal ini adalah anak tunagrahita. Dilihat dari ciri khasnya bahwa anak tunagrahita ini perlu perhatian dan pelayanan khusus. Oleh karena itu, lembaga pendidikan sangat penting dalam membantu dan memfasiliasi anak tunagrahita untuk menstimulus intelektualnya dan juga cara dalam berinteraksi, bergaul dengan orang lain.

Tempat untuk menaungi anak berkebutuhan khusus dalam hal ini adalah anak tunagrahita yaitu Sekolah Luar Biasa. Pembelajaran yang diberikan pada dasarnya sama dengan pembelajaran untuk anak umum lainnya termasuk mata pelajaran Pendidikan Jasamani. Inti pokok yang membedakannya hanyalah pembelajarannya harus dirancang sesuai dengan kebutuhan anak tunagrahita.

Berkaitan dengan pembelajaran Pendidikan Jasmani yang banyak melibatkan aktivitas fisik bahwa dengan kemampuan intelektual mereka yang di bawah rata-rata maka sedikit banyaknya berpengaruh kepada kemampuan geraknya. Berdasarkan hasil observasi (analisis kebutuhan) yang dilakukan oleh peneliti terhadap anak tunagrahita dalam hal ini peneliti fokus kepada anak tunagrahita sedang untuk tingkat Sekolah Dasar di Sekolah Luar Biasa di Kota Palembang didapat bahwa kemampuan gerak dasarnya terlihat canggung, kurang proporsional, tidak luwes atau kaku terutama pada gerak dasar lokomotornya yang terdiri dari gerak dalam berjalan, berlari, melompat dan merangkak.

Melihat dari hasil observasi peneliti maka diperlukan sebuah pemecahan masalah bagaimana cara untuk meningkatkan kemampuan gerak 
dasar lokomotor anak tunagrahita sedang. Disini peneliti mengembangkan sebuah model dengan pendekatan bermain untuk membantu anak tunagrahita sedang dalam meningkatkan kemampuan gerak dasar lokomotornya (berjalan, berlari, melompat dan merangkak). Pendekatan bermain dipilih dikarenakan mempertimbangkan karakteristik anak tunagrahita sedang yang susah dalam berinteraksi dengan orang lain, mudah bosan dalam melakukan suatu aktivitas dan kemampuan kemapuan intelektualnya yg kurang. Jadi dengan bermain mereka merasa senang, bergembira dimana tanpa mereka sadari bahwa kita telah memberinya terapi yang bermanfaat untuk memperbaiki gerak dasar lokomotornya. Hal ini sejalan dengan pendapat dari Kenneth (2007) yang mengatakan bahwa "Play is essential to development because it contributes to the cognitive, physical, social and emotional well-being of children and youth. Play also offers an ideal opportunity for parents to engage fully with their children". Dapat kita artikan bahwa bermain itu penting dalam perkembangan karena berpengaruh terhadap kognitif, fisik, sosial emosional anak-anak dan remaja. Bermain juga memberikan kesempatan bagi orang tua untuk terlibat dalam perkembangan anak-anaknya. Oleh karena itu diharapkan dengan bermain akan dapat membantu, memperbaiki dan meningkatkan gerak dasar lokomotor untuk anak tunagrahita sedang.

\section{METODE}

Penelitian ini merupakan penelitian pengembangan (research \& development). Rancangan penelitiannya menggunakan rancangan dari Borg \& Gall (2007) yang terdiri dari 10 tahap/ langkah yaitu (1) research and information collecting, (2) planning, (3) develop primary form of product, (4) preliminary field, (5) main product revision, (6) main field testing, operational product revision, (8) operational field testing. (9) final product revision, dan (10) dessimination and implementation. Sampel dalam penelitian ini adalah anak tunagrahita sedang tingkat Sekolah Dasar. Penelitian ini dilaksanakan di Kota Palembang dengan 3 tempat pelaksanaan penelitian yang terdiri dari SD SLB Karya Ibu, SD SLB YPAC dan SD SLB Pembina .

\section{HASIL DAN PEMBAHASAN \\ Hasil}
1. Evaluasi Para Pakar/Ahli (Expert Judgment) dan Revisi Produk Awal

Tahap ini adalah tahap untuk mengevaluasi produk yang sudah dibuat oleh peneliti. Selain mengevaluasi, para ahli/pakar juga memberikan masukan/saran terhadap produk yang dihasilkan agar produk tersebut lebih tepat dan siap digunakan untuk diuji cobakan. Oleh karena itu, peneliti memperbaiki produk yang dibuat berdasarkan masukan dan saran dari para pakar/ahli tersebut

Produk ini dievaluasi oleh para pakar/ahli yang terdiri dari 3 orang expert di bidang pendidikan jasmani adaptif terdiri dari Dr. Syafardudin, M. Kes., Sarjono, S.Pd. dan Novri Yetti, S.Pd. dan 3 orang yang expert di bidang motorik terdiri dari Dr. Widiastuti, M.Pd., Dr. Iyakrus, M. Pd. dan Nana Suryana, S.Pd. Jadi, total expert berjumlah 6 orang. Pakar/ ahli melakukan evaluasi berdasarkan kepakaran mereka masing-masing.

Hasil evaluasi terhadap produk yaitu produk yang semula berjumlah 48 variasi produk menjadi 42 variasi produk yang layak dan dapat dilanjutkan ke tahap selanutnya. Adapun rinciannya adalah sebagai 
berikut : berjalan gugur 2 variasi produk , melompat gugur 2 variasi produk, berlari gugur 1 variasi produk dan merangkak gugur 1 variasi produk.

Masukan dan saran dari para pakar/ahli menekankan kepada tingkat keamanan dan kenyamanan peralatan yang digunakan mengingat bahwa tingkat emosional anak tunagrahita sedang yang tidak stabil dan cenderung cepat berubah-ubah sehingga akan dapat mempengaruhi aktivitasnya. Berikut adalah hasil evaluasi pakar/ahli yang dapat dilihat pada tabel di bawah ini :

Tabel 1. Hasil Evaluasi Para Pakar (Expert Judgment)

\begin{tabular}{|c|c|c|c|c|c|}
\hline \multirow[t]{2}{*}{ No } & \multirow[t]{2}{*}{ Model } & \multicolumn{2}{|c|}{$\begin{array}{c}\text { Penerimaan Model } \\
\text { Expert Bidang Penjas } \\
\text { dan } \\
\text { Expert Bidang Motorik }\end{array}$} & \multirow[t]{2}{*}{$\begin{array}{c}\text { (Layak/Tidak } \\
\text { Layak) }\end{array}$} & \multirow[t]{2}{*}{ Masukan/Saran } \\
\hline & & Ya & Tidak & & \\
\hline & BERJALAN & & & & \\
\hline 1. & Variasi ke 1 & Ya & Ya & Layak & bisa dilaksanakan \\
\hline 2. & Variasi ke 2 & Ya & Ya & Layak & bisa dilaksanakan \\
\hline 3. & Variasi ke 3 & $\mathrm{Ya}$ & $\mathrm{Ya}$ & Layak & bisa dilaksanakan \\
\hline 4. & Variasi ke 19 & Tidak & Tidak & Tidak Layak & sulit dilaksanakan \\
\hline \multirow[t]{2}{*}{5.} & Variasi ke 20 & Tidak & Tidak & Tidak Layak & sulit dilaksanakan \\
\hline & BERLARI & & & & \\
\hline 1. & Variasi ke 1 & $\mathrm{Ya}$ & Ya & Layak & bisa dilaksanakan \\
\hline 2. & Variasi ke 2 & Ya & Ya & Layak & bisa dilaksanakan \\
\hline 3. & Variasi ke 3 & Ya & Ya & Layak & bisa dilaksanakan \\
\hline 4. & Variasi ke 4 & $\mathrm{Ya}$ & $\mathrm{Ya}$ & Layak & bisa dilaksanakan \\
\hline \multirow[t]{2}{*}{5.} & Variasi ke 5 & Tidak & Tidak & Tidak Layak & sulit dilaksanakan \\
\hline & $\begin{array}{l}\text { MELOMPAT } \\
\text { Variasi ke } 1\end{array}$ & Ya & Ya & Layak & bisa dilaksanakan \\
\hline 2. & Variasi ke 2 & Ya & Ya & Layak & bisa dilaksanakan \\
\hline 3. & Variasi ke 3 & Ya & Ya & Layak & bisa dilaksanakan \\
\hline 4. & Variasi ke 4 & Ya & Ya & Layak & bisa dilaksanakan \\
\hline 5. & Variasi ke 5 & Ya & Ya & Layak & bisa dilaksanakan \\
\hline \multirow[t]{2}{*}{6.} & Dst....variasi ke 18 & Ya & Ya & Layak & bisa dilaksanakan \\
\hline & MERANGKAK & & & & \\
\hline 1. & Variasi ke 1 & Ya & Ya & Layak & bisa dilaksanakan \\
\hline 2. & Variasi ke 2 & $\mathrm{Ya}$ & $\mathrm{Ya}$ & Layak & bisa dilaksanakan \\
\hline 3. & Variasi ke 3 & tidak & Tidak & Tidak Layak & sulit dilaksanakan \\
\hline
\end{tabular}

\section{Uji Coba Skala Kecil dan Revisi Produk}

Pada tahap ini peneliti melakukan uji coba skala kecil terhadap produk yang sudah direvisi berdasarkan masukan para pakar/ahli. Tahap ini untuk melihat apakah produk dapat diaplikasikan, dilaksanakan oleh subjek uji coba dalam hal ini adalah anak tunagrahita sedang. Uji coba ini dilaksanakan di SD SLB C Karya Ibu
Kota Palembang dengan subjek uji coba berjumlah 12 orang anak tunagrahita sedang.

Berdasarkan hasil uji coba ternyata produk tersebut dapat diaplikasikan akan tetapi tetap dengan instruksi penuh dari guru. Hal ini dikarenakan oleh karakteristik intelektual anak tunagrahita sedang yang memiliki IQ antara 40-54 yang berarti bahwa daya ingat dan daya 
tangkap terhadap intruksi tersebut sangat lamban sehingga mempengaruhi perintah tugas yang diberikan jika tidak diberikan pendampingan. Selain itu

Masukan dan saran setelah diujicobakan pada uji skala kecil ini yaitu selain pendampingan dan intruksi dari guru yang harus lebih ditekankan yaitu pendampingan terhadap personal anak tunagrahita sedang karena mereka memiliki emosional yang tidak stabil dan cepat berubah-ubah. Berikut adalah gambaran hasil uji coba skala kecil , dapat dilihat pada tabel di bawah ini :

Tabel 2. Hasil Uji Coba Skala Kecil

\begin{tabular}{|c|c|c|c|}
\hline No & Model & Masukan/Saran & Keterangan \\
\hline & BERJALAN & & \\
\hline 1. & Variasi ke 1 & Dapat diaplikasikan dengan instruksi penuh dan pendampingan lebih/ekstra. & Rubrik Penilaian \\
\hline 2. & Variasi ke 2 & Dapat diaplikasikan dengan instruksi penuh dan pendampingan lebih/ekstra. & Rubrik Penilaian \\
\hline 3. & Variasi ke 3 & Dapat diaplikasikan dengan instruksi penuh dan pendampingan lebih/ekstra. & Rubrik Penilaian \\
\hline 4. & Variasi ke 4 & Dapat diaplikasikan dengan instruksi penuh dan pendampingan lebih/ekstra. & Rubrik Penilaian \\
\hline 5. & Variasi ke 5 & Dapat diaplikasikan dengan instruksi penuh dan pendampingan lebih/ekstra. & Rubrik Penilaian \\
\hline \multirow[t]{2}{*}{6.} & Dst....variasi ke 18 & Dapat diaplikasikan dengan instruksi penuh dan pendampingan lebih/ekstra. & Rubrik Penilaian \\
\hline & BERLARI & & \\
\hline 1. & Variasi ke 1 & Dapat diaplikasikan dengan instruksi penuh dan pendampingan lebih/ekstra. & Rubrik Penilaian \\
\hline 2. & Variasi ke 2 & Dapat diaplikasikan dengan instruksi penuh dan pendampingan lebih/ekstra. & Rubrik Penilaian \\
\hline 3. & Variasi ke 3 & Dapat diaplikasikan dengan instruksi penuh dan pendampingan lebih/ekstra. & Rubrik Penilaian \\
\hline \multirow[t]{2}{*}{4.} & Variasi ke 4 & Dapat diaplikasikan dengan instruksi penuh dan pendampingan lebih/ekstra. & Rubrik Penilaian \\
\hline & MELOMPAT & & \\
\hline 1. & Variasi ke 1 & Dapat diaplikasikan dengan instruksi penuh dan pendampingan lebih/ekstra. & Rubrik Penilaian \\
\hline 2. & Variasi ke 2 & Dapat diaplikasikan dengan instruksi penuh dan pendampingan lebih/ekstra. & Rubrik Penilaian \\
\hline 3. & Variasi ke 3 & Dapat diaplikasikan dengan instruksi penuh dan pendampingan lebih/ekstra. & Rubrik Penilaian \\
\hline 4. & Variasi ke 4 & Dapat diaplikasikan dengan instruksi penuh dan pendampingan lebih/ekstra. & Rubrik Penilaian \\
\hline 5. & Variasi ke 5 & Dapat diaplikasikan dengan instruksi penuh dan pendampingan lebih/ekstra. & Rubrik Penilaian \\
\hline \multirow[t]{2}{*}{6.} & Dst....variasi ke 18 & Dapat diaplikasikan dengan instruksi penuh dan pendampingan lebih/ekstra. & Rubrik Penilaian \\
\hline & MERANGKAK & & \\
\hline 1. & Variasi ke 1 & Dapat diaplikasikan dengan instruksi penuh dan pendampingan lebih/ekstra. & Rubrik Penilaian \\
\hline 2. & Variasi ke 2 & Dapat diaplikasikan dengan instruksi penuh dan pendampingan lebih/ekstra. & Rubrik Penilaian \\
\hline
\end{tabular}

\section{Uji Coba Skala Besar dan Revisi Produk}

Setelah uji coba skala kecil selanjutnya adalah uji coba skala besar. Sebelum memulai tahap uji coba skala besar, peneliti memperbaiki produk sesuai masukan dan saran sesuai hasil uji coba skala kecil.. Uji coba ini dilaksanakan di SD SLB C Karya Ibu Kota Palembang, SD SLB C YPAC Kota Palembang dan SD SLB B Pembina Kota Palembang dengan subjek uji coba berjumlah 36 orang anak tunagrahita sedang.

Berdasarkan hasil uji coba ternyata hasil uji coba skala besar hampir sama dengan hasil uji coba skala kecil yaitu dapat diaplikasikan akan tetapi tetap dengan instruksi penuh dari guru.

Revisi produk untuk tahap ini sudah tidak lagi dilakukan dikarenakan produk sudah memunuhi segala aspek untuk diterapkan sehingga layak untuk digunakan bagi guru dan dapat 
diaplikasikan ke anak tunagrahita terutama tunagrahita sedang. Untuk lebih jelasnya dapat dilihat pada tabel di bawah ini :

Tabel 3. Hasil Uji Coba Skala Besar

\begin{tabular}{|c|c|c|c|}
\hline No & Model & Masukan/Saran & Keterangan \\
\hline & BERJALAN & & \\
\hline 1. & Variasi ke 1 & Dapat diaplikasikan dengan instruksi penuh dan pendampingan lebih. & Rubrik Penilaian \\
\hline 2. & Variasi ke 2 & Dapat diaplikasikan dengan instruksi penuh dan pendampingan lebih. & Rubrik Penilaian \\
\hline 3. & Variasi ke 3 & Dapat diaplikasikan dengan instruksi penuh dan pendampingan lebih. & Rubrik Penilaian \\
\hline 4. & Variasi ke 4 & Dapat diaplikasikan dengan instruksi penuh dan pendampingan lebih. & Rubrik Penilaian \\
\hline 5. & Variasi ke 5 & Dapat diaplikasikan dengan instruksi penuh dan pendampingan lebih. & Rubrik Penilaian \\
\hline 6. & Dst....variasi ke 18 & Dapat diaplikasikan dengan instruksi penuh dan pendampingan lebih. & Rubrik Penilaian \\
\hline
\end{tabular}

\section{BERLARI}

1. Variasi ke 1

2. Variasi ke 2

3. Variasi ke 3

4. Variasi ke 4

\footnotetext{
Dapat diaplikasikan dengan instruksi penuh dan pendampingan lebih. Rubrik Penilaian Dapat diaplikasikan dengan instruksi penuh dan pendampingan lebih. Rubrik Penilaian Dapat diaplikasikan dengan instruksi penuh dan pendampingan lebih. Rubrik Penilaian Dapat diaplikasikan dengan instruksi penuh dan pendampingan lebih. Rubrik Penilaian
}

\section{MELOMPAT}

1. Variasi ke 1

2. Variasi ke 2

3. Variasi ke 3

4. Variasi ke 4

5. Variasi ke 5

6. Dst....variasi ke 18 $\begin{array}{ll}\text { Dapat diaplikasikan dengan instruksi penuh dan pendampingan lebih. } & \text { Rubrik Penilaian } \\ \text { Dapat diaplikasikan dengan instruksi penuh dan pendampingan lebih. } & \text { Rubrik Penilaian } \\ \text { Dapat diaplikasikan dengan instruksi penuh dan pendampingan lebih. } & \text { Rubrik Penilaian } \\ \text { Dapat diaplikasikan dengan instruksi penuh dan pendampingan lebih. } & \text { Rubrik Penilaian } \\ \text { Dapat diaplikasikan dengan instruksi penuh dan pendampingan lebih. } & \text { Rubrik Penilaian } \\ \text { Dapat diaplikasikan dengan instruksi penuh dan pendampingan lebih. } & \text { Rubrik Penilaian }\end{array}$

Dapat diaplikasikan dengan instruksi penuh dan pendampingan lebih. Rubrik Penilaian Dapat diaplikasikan dengan instruksi penuh dan pendampingan lebih. Rubrik Penilaian

1. Variasi ke 1

2. Variasi ke 2

\section{Efektifitas Model}

Uji efektifitas model ini bertujuan untuk mengetahui apakah model yang dibuat efektif atau tidak digunakan. Uji ini dilaksanakan dengan membandingkan produk sebelum dan sesudah digunakan oleh anak tunagrahita sedang.

Hasil tes gerak dasar lokomotor menunjukkan adanya perbedaan dari sebelum diberikan perlakuan dan sudah diberikan perlakuan. Hal ini menunjukkan bahwa produk yag dibuat dinyatakan efektif untuk digunakan. Hasil ini dibuktikan dari hasil t hitung $>$ t tabel yaitu :17.50 > 2.028.

\section{Pembahasan}

Belajar gerak sangat penting untuk dipelajari karena dapat meningkatkan kinerja keterampilan gerak seseorang dan tanpa disadari dapat merubah perilaku seseorang. Hal ini sejalan dengan pendapat dari Magill (2011) yang mengatakan bahwa :"motor learning is the study of acquisition of motor skill, the performance enchancement of learned of highly experienced motor skills, or the reacquisition of skill that are difficult to perform or cannot be performed because injury, disease, and the like. Of interest are the behavioral and/or neurological changes that occur as a person learns a motor skill and the 
variables that influence those changes. Yang artinya adalah belajar motorik adalah studi tentang perolehan keterampilan motorik, peningkatan kinerja belajar keterampilan motorik yang sangat berpengalaman, atau perolehan kembali keterampilan yang sulit dilakukan atau tidak dapat dilakukan karena cedera, penyakit, dan sejenisnya. Menariknya adalah adanya perubahan perilaku dan/atau neurologis yang terjadi ketika seseorang setelah mereka mempelajari keterampilan motorik dan variabel yang mempengaruhi perubahan tersebut.

Belajar gerak bagi anak berkebutuhan khusus dalam hal ini adalah anak tunagrahita sedang harus disesuaikan dengan kebutuhannya dan karakteristiknya karena akan berpengaruh kepada hasil yang diharapkan dari pembelajaran. Seperti yang dikatakan Magill (2011) bahwa "transfer of learning as the influence of having previously practiced of performed a skill or skill on the learning of a new skill. This influence may be positive, negative, or neiutral (zero). Maksudnya adalah transfer dari pembelajaraan berpengaruh terhadap keterampilan yang sebelumnya pernah dilakukan dan keterampilan yang baru. Pengaruhnya dapat menjadi positif maupun negatif. Oleh karena itu harus disesuaikan dengan anak tunagrahita sedang, dalam hal ini pendekatan bermain dipilih untuk membantu dan memperbaiki/meningkatkan

kemampuan gerak dasar lokomotornya.

Sejalan dengan penelitian Indah (2015) yang menyatakan bahwa urgensinya bermain bagi anak tunagrahita dikembangkan sebagai play therapy. Dalam penelitiannya aktivitas bermain yang dipilihnya untuk meningkatkan kemampuan gerak dasar lokomotor anak tunagrahita adalah permainan tradisional. Permainan tradisional dipilih dengan dasar bahwa cocok dengan jenis kecacatan anak tunagrahita.

Tanpa disadari bahwa bermain tidak hanya bermanfaat untuk keterampilan geraknya saja akan tetapi membantu meningkatkan pengetahuannya (kognitif), jasmaninya dan yang tak kalah penting adalah sosial emosionalnya. Gerak lokomotor dalam penelitian ini yang terdiri dari gerak berjalan, berlari, melompat dan merangkak dikemas dengan pendekatan bermain. Permainannya yang sederhana, mudah dipahami tidak sukar dilakukan dan perlombaan.

\section{SIMPULAN DAN SARAN}

Berdasarkan hasil dari penelitian bahwa permainan gerak dasar lokomotor untuk anak tunagrahita sedang dapat diaplikasikan akan tetapi dengan intruksi guru dan tetap dengan pendampingan. Oleh karena itu bagi guru, pelatih dan orang tua agar dapat memberikan belajar gerak dasar bagi anak tunagrahita sedang melaluli permainan yang sederhana dan tingkat gerak yang sederhana/mudah.

\section{DAFTAR PUSTAKA}

Borg, W.R. \& Gall, M.D. 2007., Educational Research An Introduction. Longman New, York.

Indah, Yuniar Utari. 2015. Upaya Meningkatkan Gerak Dasar Lokomotor Anak Tunagrahita Ringan Melalui Permainan Tradisional (Pada Siswa-Siswi Sekolah Dasar Luar Biasa Tunas Mulya Surabaya). Jurnal Pendidikan Olahraga dan Kesehatan, 3 (2), 279-282.

Kemis dan Ati, Rosnawati. 2013. Pendidikan Anak Berkebutuhan 
Khusus Tunagrahita. Jakarta Timur : PT. Luxima Metro Media.

Kenneth, R. Ginsburg. 2007. American Journal Academy of Pediatric, Vol. 119 No. 1, 1 Januari 2007. 182-191

Magil, A. Richard. 2011. Motor Learning and Control Concepts and Application (9thed). New York: McGraw-Hill.

Rachmayan, Dadan. 2013. Diantara Pendidikan Luar Biasa Menuju Anak Masa Depan Yang Inklusif. Jakarta Timur : Luxima.

Somantri, Sutjihati. 2007. Psikologi Anak Luar Biasa. Bandung : Refika Aditama. 